\title{
Efektivitas pendekatan rational emotive behavior therapy untuk mengatasi perilaku bullying siswa
}

\author{
Erismon Erismon $^{\left.1^{*}\right)}$, Yeni Karneli ${ }^{2}$ \\ ${ }^{12}$ Universitas Negeri Padang
}

\section{Article Info \\ Article history: \\ Received Des $20^{\text {th }}, 2020$ \\ Revised Jan $06^{\text {th }}, 2021$ \\ Accepted Jan 20 ${ }^{\text {th }}, 2021$}

\section{Keyword:}

Rational emotive behavior therapy

Bullying

\begin{abstract}
Penelitian ini bertujuan untuk mendeskripsikan efektivitas pendekatan rational emotive behavior threapy dalam mengatasi perilaku bullying siswa. Rancangan penelitian ini menggunakan pendekatan kuantitatif eksperimen. Sampel dalam penelitian ini adalah siswa yang perilaku bullying sebanyak 20 orang. 10 orang untuk pelaksanaan kelompok eksperimen dan 10 orang untuk pelaksanaan kelompok kontrol. Instrument penelitian ini menggunakan skala perilaku bullying siswa yang telah memenuhi syarat instrumen penelitian, kemudian data di analisis dengan menggunakan uji Wilcoxon Signed Rank Test dan Uji Kolmogorov Smirnov 2 Independent Samples. Hasil penelitian menunjukkan bahwa: 1) Terdapat perbedaan yang signifikan perilaku bullying peserta didik kelompok eksperimen sebelum dan sesudah mengikuti pendekatan rational emotive behavior therapy format kelompok. 2) Terdapat perbedaan yang signifikan perilaku bullying peserta didik kelompok kontrol sebelum dan sesudah mengikuti layanan bimbingan kelompok tanpa menggunakan pendekatan rational emotive behavior therapy. 3) Terdapat perbedaan yang signifikan perilaku bullying peserta didik kelompok eksperimen yang diberikan pendekatan rational emotive behavior therapy format kelompok dengan peserta didik kelompok kontrol yang diberikan layanan konseling kelompok tanpa pendekatan rational emotive behavior therapy. kelompok eksperimen dan kontrol sama-sama mengalami penurunan, akan tetapi rata-rata penurunan kelompok eksperimen lebih besar pada kelompok kontrol.
\end{abstract}

(C) 2021 The Authors. Published by IICET.

This is an open access article under the CC BY-NC-SA license (https://creativecommons.org/licenses/by-nc-sa/4.0)

\section{Corresponding Author:}

Erismon Erismon

Universitas Negeri Padang

Email: emon.marta951015@gmail.com

\section{Pendahuluan}

Sekolah merupakan tempat proses pembelajaran para peserta didik mengembangkan berbagai potensi yang mereka miliki. Sekolah berpengaruh besar terhadap perkembangan peserta didik. Sekolah seharusnya menjadi tempat yang nyaman, menyenangkan dan tempat yang sehat berlangsungnya proses pembelajaran. Namun, bagi sebagian peserta didik ternyata lingkungan sekolah tidak selalu nyaman dan menyenangkan, malah sebaliknya bisa membuat mereka menjadi stress, cemas dan takut. Salah satu penyebab ketidak nyamanan adalah adanya perilaku bullying di sekolah. Bullying terjadi pada semua tingkatan sekolah mulai dari Taman Kanak-kanak hingga Perguruan Tinggi (Ani Wardah, 2019).

Kasus perundungan (bullying) sudah menjadi bagian yang sulit dipisahkan dari ragam kehidupan masyarakat. Bullying seolah menjadi sub kebudayaan yang melekat di masyarakat. Bullying telah merasuk ke 
berbagai sektor kehidupan, baik sosial, budaya, politik hingga ancaman keamanan. Dunia pendidikan, terutama sekolah menyumbangkan akumulasi kasus bullying yang cukup besar (Nurhadiyanto \& Luhur, 2020)

Prevalensi bullying di sekolah meningkat setiap tahunnya dan terjadi di berbagai negara dunia. Berdasarkan Penelitian Hinduja \& Patchin (2017) mengungkapkan bahwa di Amerika Serikat 70\% siswa menjadi korban bullying. Kasus bullying juga terjadi di sekolah-sekolah di Jepang yaitu 43,8\% (Yasinta, 2017). Sedangkan, data dari UNESCO (2018) yang melibatkan 144 negara mengungkapkan bahwa 16,1\% anak-anak pernah menjadi korban bullying secara fisik (Yanti, 2020).

Indonesia merupakan Negara yang menempati posisi teratas kasus bullying di sekolah pada tingkat Asean, yaitu 84\%, disusul Nepal dan Vietnam 79\%, Kamboja 73\% dan Pakistan 43\% (KPAI, 2017). Berdasarkan laporan KPAI pada periode 2011-2017 menerima 26.000 kasus perlindungan anak, dimana 34\% dari kasus tersebut adalah kasus bullying. Sedangkan laporan KPAI (2018) data bidang pendidikan melaporkan bahwa dari 161 kasus dengan rincian: anak korban tawuran sebanyak 23 kasus atau 14,3\%, anak pelaku tawuran sebanyak 31 kasus atau 19,3\%, anak korban kekerasan dan bullying sebanyak 36 kasus atau 22,4\%, anak pelaku kekerasan dan bullying sebanyak 41 kasus atau 25,5\%, dan anak korban kebijakan (pungli, dikeluarkan dari sekolah, tidak boleh ikut ujian, dan putus sekolah) sebanyak 30 kasus atau 18,7\%. Permasalahan pada anak yang paling tinggi adalah bullying di sekolah yakni 77 kasus atau 47,9\%. Berdasarkan laporan KPAI (2019) menerima pengaduan 153 kasus yang terdiri dari anak korban kebijakan, anak korban kekerasan fisik dan bullying (Sri Rahma Yanti, 2020).

Berdasarkan laporan dari UPTD PPA Sumatera Barat bulan Januari sampai September 2019 terdapat 30 kasus anak korban bullying yang melapor dan ditangani. Data Sistem Informasi Online Perlindungan Perempuan dan Anak (SIMFONI PPA) jumlah kekerasan di Sumatera Barat terjadi peningkatan yang signifikan, pada tahun 2018 terdapat 39 kasus dan tahun 2019 keadaan Juni terdapat sebanyak 43 kasus. Berdasarkan tempat kejadian perilaku kekerasan dan bullying di Sekolah Kota Padang berada di peringkat pertama dengan 6 kasus dari 19 kasus (Putra, 2020).

Berdasarkan wawancara dengan guru bimbingan dan konseling di SMP Hamka II Padang pada tanggal 1 September 2019 bahwa maraknya perilaku bullying yang paling banyak dilakukan adalah bullying verbal seperti mengejek teman dan memanggil teman dengan panggilan yang tidak disukai, disusul dengan bullying fisik seperti memukul, menendang dan mendorong teman, selanjutnya bullying non verbal juga didapati seperti mengajak teman untuk menjauhi teman yang lain. Dari 95 kasus, terdapat 63 kasus yang berkaitan dengan perilaku bullying, dengan rincian bullying verbal 33 kasus, bullying fisik 18 kasus dan bullying non verbal 12 kasus.

Hal ini sangat memprihatinkan karena terjadi di lingkungan sekolah yang syarat akan penanaman nilai pendidikan, dan tentu bertentangan dengan tujuan pendidikan nasional. Sebagaimana UU no 20 tahun 2003 pasal 3 yang menyebutkan bahwa: Pendidikan nasional berfungsi mengembangkan kemampuan dan membentuk watak serta peradaban bangsa yang bermartabat dalam rangka mencerdaskan kehidupan bangsa, bertujuan untuk berkembangnya potensi peserta didik agar menjadi manusia yang beriman dan bertaqwa kepada Tuhan yang Maha Esa, berakhlak mulia, sehat, berilmu, cakap, kreatif, mandiri, dan menjadi warga negara yang demokratis dan bertanggung jawab.

Untuk mengantisipasi munculnya perilaku bullying lain yang lebih membahayakan, maka diperlukan skala nilai baru dan sistem norma yang dapat mengarahkan perilaku, mengendalikan bahkan mencegah keinginankeinginan individu yang tidak bisa diterima oleh umum. Berdasarkan permasalahan yang telah diuraikan, untuk itu peneliti melakukan penelitian tentang efektifan pendekatan rational emotive behavior therapy dalam mengatasi bullying siswa.

Sebagai alasan konkrit menggunakan pendekatan rational emotive behavior threapy, bahwa pendekatan ini telah merancang dan menekankan interaksi berpikir yang rasional (Rational Thingking), perasaan (Emoting) dan tingah laku (Acting). Ellis, menjelaskan bahwa pendekatan rational emotive behavior therapy adalah system psikoterapi yang mengajari individu bagaimana system keyakinannya menentukan yang dirasakan dan dilakukannya pada berbagai peristiwa dalam kehidupan (Dryden, 2006).

\section{Method}

Rancangan eksperimen yang digunakan dalam penelitian ini adalah rancangan eksperimen model Quasi Eksperiment, dengan desain penelitian The Non Equivalent Control Group, rancangan ini terdiri dari dua keompok yaitu kelompok eksperimen dan kelompok control. Penelitian ini dilakukan di SMP Hamka II Padang. Populasi penelitian adalah siswa kelas VIII SMP Hamka II Padang sebanyak 60 siswa. sampel dalam penelitian ini sebanyak 20 siswa. Instrumen yang digunakan pada penelitian ini adalah skala perilaku bullying 
siswa. Adapun teknik analisis data menggunakan statistik nonparametrik dengan Uji Wilcoxon Singed Rank Test dan Uji Kolmogorov Smirnov 2 Indevendent. dengan tujuan melihat perbedaan perilaku bullying subjek penelitian sebelum diberikan perlakuan dengan kondisi perilaku bullying subjek penelitian sesudah diberikan perlakuan. Deskripsi data dilakukan melalui analisis data berdasarkan hasil dari uji hi potesis dengan menggunakan bantuan program SPSS versi 20.00

\section{Hasil dan Pembahasan}

Data yang diperoleh kemudian dilakukan analisis, teknik analisis diklasifikasikan dengan kategori sangat tinggi, tinggi, sedang, rendah dan sangat rendah. Adapun pengkategorian stres akademik siswa adalah sebagai berikut:

Tabel 1. Gambaran awal perilaku bullying siswa

\begin{tabular}{cccc}
\hline Skor & Kategori & $\mathbf{F}$ & $\mathbf{\%}$ \\
\hline $\mathbf{1 5 3} \geq$ & Sangat Tinggi & 0 & $0 \%$ \\
\hline $\mathbf{1 2 4 - 1 5 2}$ & Tinggi & 16 & $27 \%$ \\
\hline $\mathbf{9 5 - 1 2 3}$ & Sedang & 12 & $20 \%$ \\
\hline $\mathbf{6 6 - 9 4}$ & Rendah & 22 & $36 \%$ \\
\hline$\leq \mathbf{6 5}$ & Sangat Rendah & 10 & $17 \%$ \\
\hline & Jumlah & 60 & $100 \%$ \\
\hline
\end{tabular}

Pretest dilakukan dengan tujuan untuk mengetahui gambaran awal tentang perilaku bullying sebelum diberikan perlakuan pendekatan rational emotive behavior therapy. Kelompok kelas subjek penelitian berjumlah 60 orang yang terdiri dari 31 orang siswa kelas VIII 3 dan 29 orang siswa kelas VIII 4. Setelah pengolahan data pretes maka dipilih secara heterogen siswa yang akan menjadi anggota kelompok eksperimen dan kontrol dengan pengkategorian perilaku bullying sangat tinggi, tinggi, sedang, rendah dan sangat rendah. Jumlah subjek penelitian yaitu 10 orang kelompok eksperimen dan 10 orang anggota kelompok kontrol. Dasar pertimbangan pemilihan anggota kelompok yang heterogen adalah untuk menciptakan dinamika kelompok. Adapun hasil pretest yang diperoleh pada kelompok eksperimen adalah sebagai berikut :

Tabe1 2. Kondisi Pretest Perilaku Bullying Masing-masing Siswa pada Kelompok Eksperimen

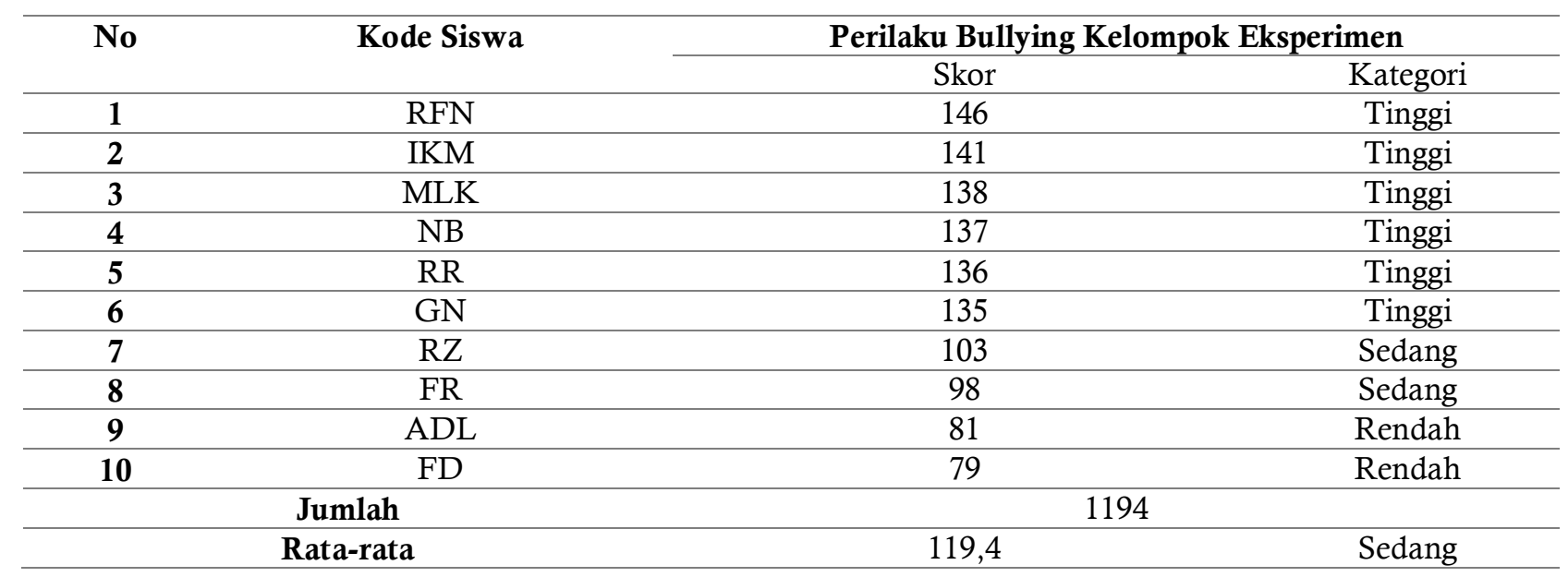

Berdasarkan Tabel 2, dapat dilihat bahwa rata-rata skor sebelum kegiatan bimbingan kelompok pada variabel perilaku bullying kelompok eksperimen sebesar 119,4 dengan kategori sedang. Berdasarkan pengolahan hasil pretes kegiatan bimbingan kelompok diperoleh gambaran kondisi perilaku bullying peserta didik pada kelompok eksperimen, dari 10 siswa pada kelompok eksperimen, dipilih 6 orang siswa yang memiliki perilaku bullying tinggi, 2 orang kategori sedang, dan 2 orang kategori rendah. Bervariasinya skor sikap siswa terhadap perilaku bullying bertujuan untuk menciptakan dinamika kelompok dalam kegiatan bimbingan kelompok, sehingga masing-masing kelompok bisa bertukar pikiran dan pendapat mengenai perilaku bullying.

\section{Hasil posttes kelompok eksperimen}

Pemberian instrumen posttes kepada kelompok ekperimen dilakukan enam hari setelah kegiatan bimbingan kelompok sesi ke 3 berakhir yaitu tanggal 25 Desember 2020. Posttest diberikan berguna untuk mengetahui 
perbedaan stres akademik siswa. Adapun hasil pengolahan hasil posttest kelompok eksperimen adalah sebagai berikut:

Tabel 3. Hasil posttest perilaku bullying masing-masing siswa kelompok eksperimen

\begin{tabular}{|c|c|c|c|}
\hline \multirow[t]{2}{*}{ No } & \multirow{2}{*}{ Kode Siswa } & \multicolumn{2}{|c|}{ Perilaku Bullying Kelompok Eksperimen } \\
\hline & & Skor & Kategori \\
\hline 1 & RFN & 98 & Sedang \\
\hline 2 & IKM & 99 & Sedang \\
\hline 3 & MLK & 84 & Rendah \\
\hline 4 & NB & 81 & Rendah \\
\hline 5 & $\mathrm{RR}$ & 83 & Rendah \\
\hline 6 & GN & 76 & Rendah \\
\hline 7 & RZ & 63 & Sangat Rendah \\
\hline 8 & FR & 54 & Sangat Rendah \\
\hline 9 & ADL & 57 & Sangat Rendah \\
\hline 10 & FD & 58 & Sangat Rendah \\
\hline \multicolumn{2}{|c|}{ Jumlah } & \multicolumn{2}{|c|}{753} \\
\hline & ta-rata & 75,3 & Rendah \\
\hline
\end{tabular}

Berdasarkan tabel 3, terjadi penurunan perilaku bullying siswa setelah diberikan pelakuan pendekatan REBT dalam format kelompok. Secara keseluruhan penurunan terjadi pada jumlah perolehan skor dan kategori perilaku bullying. Sebelumnya 6 orang peserta didik dengan kategori tinggi, 2 orang kategori sedang dan 2 orang katagori rendah. Setelah diberikan layanan pendekatan REBT dalam format kelompok maka 2 orang anggota kelompok memiliki perilaku bullying berada pada kategori sedang , 4 orang anggota kelompok berada pada kategori rendah dan 4 orang anggota kelompok berada pada kategori sangat rendah rendah. Hal ini berarti tidak ada lagi anggota kelompok yang memiliki perilaku bullying tinggi. Anggota kelompok sudah memahami dan mengetahui bahwa perilaku bullying dapat merugikan orang lan dan dirinya sendiri.

Perbedaan hasil pretes dan posttes kelompok eksperimen

Selanjutnya, untuk mengetahui perbandingan sikap siswa terhadap perilaku bullying kelompok eksperimen sebelum diberikan dan setelah diberikan pelakuan dengan menggunakan pendekatan REBT dalam format kelompok dapat dilihat dalam tabel berikut:

Tabel 4. Perbandingan perilaku bullying siswa pretest dan posttest kelompok eksperimen

\begin{tabular}{ccccccc}
\hline \multirow{2}{*}{ No } & \multirow{2}{*}{ Kode Siswa } & \multicolumn{2}{c}{ Pretest } & \multicolumn{2}{c}{ Posttest } & Selisih Skor \\
\cline { 3 - 6 } & & Skor & Kategori & Skor & Kategori & \\
\hline $\mathbf{1}$ & RFN & 146 & Tinggi & 98 & Sedang & 48 \\
\hline $\mathbf{2}$ & IKM & 141 & Tinggi & 99 & Sedang & 42 \\
\hline $\mathbf{3}$ & MLK & 138 & Tinggi & 84 & Rendah & 54 \\
\hline $\mathbf{4}$ & NB & 137 & Tinggi & 81 & Rendah & 56 \\
\hline $\mathbf{5}$ & RR & 136 & Tinggi & 83 & Rendah & 53 \\
\hline $\mathbf{6}$ & GN & 135 & Tinggi & 76 & Rendah & 59 \\
\hline $\mathbf{7}$ & RZ & 103 & Sedang & 63 & Sangat Rendah & 40 \\
\hline $\mathbf{8}$ & FR & 98 & Sedang & 54 & Sangat Rendah & 44 \\
\hline $\mathbf{9}$ & ADL & 81 & Rendah & 57 & Sangat Rendah & 24 \\
\hline $\mathbf{1 0}$ & FD & 79 & Rendah & 58 & Sangat Rendah & 21 \\
\hline & Jumlah & \multicolumn{7}{c}{1194} & 753 & 441 \\
\hline & Rata-rata & 119,4 & Sedang & 75,3 & Rendah & 44,1 \\
\hline
\end{tabular}

Berdasarkan tabel 4, terlihat bahwa secara keseluruhan terjadi penurunan perilaku bullying kelompok eksperimen setelah diberikan perlakuana pendekatan REBT dalam format kelompok. Dari tingkat perilaku bullying siswa sedang, setelah diberikan pendekatan REBT dalam format kelompok menurun menjadi rendah. Rata-rata keseluruhan menunjukan penurunan dari 119,4 menjadi 75,3 dengan rata-rata selisih penurunan sebanyak 44,1dan jumlah total skor penurunan antara pretest dan posttest adalah 441 . Selain itu, tingkat pengkategorian perilaku bullying siswa menurun dari kategori sedang menjadi rendah. Hal ini berarti terdapat penurunan perilaku bullying siswa pada kelompok eksperimen yang diberikan perlakuan pendekatan REBT 
dalam format kelompok. Selanjutnya, perbedaan frekuensi perilaku bullying siswa untuk masing-masing kategori dari hasil pretest dan posttest kelompok eksperimen dapat dilihat sebagai berikut:

\section{Hasil pretest dan posttes kelompok kontrol}

Hasil pretes

Adapun hasil pretest yang diperoleh pada kelompok kontrol sebelum kegiatan bimbingan kelompok adalah sebagai berikut:

Tabe1 5. Kondisi pretest perilaku bullying siswa kelompok kontrol

\begin{tabular}{cccc}
\hline \multirow{2}{*}{ No } & Kode Siswa & \multicolumn{2}{c}{ Perilaku Bullying Kelompok Kontrol } \\
\cline { 3 - 4 } & & Skor & Kategori \\
\hline $\mathbf{1}$ & ZK & 142 & Tinggi \\
\hline $\mathbf{2}$ & TR & 140 & Tinggi \\
\hline $\mathbf{3}$ & FR & 138 & Tinggi \\
\hline $\mathbf{4}$ & FS & 137 & Tinggi \\
\hline $\mathbf{5}$ & FD & 135 & Tinggi \\
\hline $\mathbf{6}$ & IBN & 132 & Tinggi \\
\hline $\mathbf{7}$ & KZ & 97 & Sedang \\
\hline $\mathbf{8}$ & RM & 96 & Sedang \\
\hline $\mathbf{9}$ & EZ & 82 & Rendah \\
\hline $\mathbf{1 0}$ & FJ & 81 & Rendah \\
\hline & Jumlah & \multicolumn{2}{c}{} \\
\hline & Rata-Rata & 118 & Sedang \\
\hline
\end{tabular}

Tabel 5, dapat dilihat bahwa rata-rata skor perilaku bullying siswa sebelum kegiatan bimbingan kelompok sebesar 118. Hal ini berarti rata-rata skor kelompok eksperimen dan kontrol sama. Berdasarkan pengolahan hasil pretes kegiatan bimbingan kelompok diperoleh gambaran kondisi perilaku bullying pada kelompok kontrol, dari 10 siswa pada kelompok kontrol, dipilih masing-masing kelompok 6 orang dengan kategori tinggi, 2 orang kategori sedang, dan 2 orang kategori rendah.

\section{Hasil posttes kelompok kontrol}

Pemberian instrumen posttes kepada kelompok kontrol dilakukan enam hari setelah kegiatan bimbingan kelompok yaitu tanggal 26 desember 2020. Adapun hasil pengolahan hasil posttes kelompok kontrol adalah sebagai berikut:

Tabel 6. Hasil posttest perilaku bullying siswa kelompok kontrol

\begin{tabular}{cccc}
\hline \multirow{2}{*}{ No } & Kode Siswa & \multicolumn{2}{c}{ Perilaku Bullying Kelompok Kontrol } \\
\cline { 2 - 4 } & & Skor & Kategori \\
\hline $\mathbf{1}$ & ZK & 120 & Sedang \\
\hline $\mathbf{2}$ & TR & 114 & Sedang \\
\hline $\mathbf{3}$ & FR & 112 & Sedang \\
\hline $\mathbf{4}$ & FS & 114 & Sedang \\
\hline $\mathbf{5}$ & FD & 110 & Sedang \\
\hline $\mathbf{6}$ & IBN & 115 & Sedang \\
\hline $\mathbf{7}$ & KZ & 95 & Sedang \\
\hline $\mathbf{8}$ & RM & 92 & Rendah \\
\hline $\mathbf{9}$ & EZ & 82 & Rendah \\
\hline $\mathbf{1 0}$ & FJ & 79 & Rendah \\
\hline & Jumlah & & \\
\hline & Rata-Rata & 103,3 & Sedang \\
\hline
\end{tabular}

Berdasarkan tabel 6, terlihat bahwa terjadi penurunan perilaku bullying siswa setelah diberikan bimbingan kelompok tanpa menggunakan pendekatan REBT. Secara keseluruhan terjadi penurunan jumlah perolehan skor terhadap perilaku bullying. Sebelumnya 6 orang dengan kategori tinggi, 2 orang kategori sedang dan 2 orang katagori rendah. Setelah diberikan layanan bimbingan kelompok tanpa menggunakan pendekatan REBT maka perilaku bullying siswa 7 orang dalam kategori sedang dan 3 orang dalam katagori rendah. 


\section{Perbedaan hasil pretes dan posttes kelompok kontrol}

Selanjutnya, untuk mengetahui perbandingan stres akademik siswa kelompok kontrol sebelum diberikan dan setelah diberikan pendekatan REBT melalui layanan bimbingan kelompok dapat dilihat dalam Tabel berikut

Tabel 7. Perbandingan hasil pretest dan posttest perilaku bullying siswa kelompok kontrol

\begin{tabular}{|c|c|c|c|c|c|c|}
\hline \multirow[t]{2}{*}{ No } & \multirow[t]{2}{*}{ Kode Siswa } & \multicolumn{2}{|c|}{ Pretest } & \multicolumn{2}{|c|}{ Posttest } & \multirow[t]{2}{*}{ Selisih Skor } \\
\hline & & Skor & Kategori & Skor & Kategori & \\
\hline 1 & ZK & 142 & Tinggi & 120 & Sedang & 22 \\
\hline 2 & TR & 140 & Tinggi & 114 & Sedang & 26 \\
\hline 3 & FR & 138 & Tinggi & 112 & Sedang & 26 \\
\hline 4 & FS & 137 & Tinggi & 114 & Sedang & 23 \\
\hline 5 & FD & 135 & Tinggi & 110 & Sedang & 25 \\
\hline 6 & IBN & 132 & Tinggi & 115 & Sedang & 17 \\
\hline 7 & $\mathrm{KZ}$ & 97 & Sedang & 95 & Seadang & 2 \\
\hline 8 & RM & 96 & Sedang & 92 & Rendah & 4 \\
\hline 9 & $\mathrm{EZ}$ & 82 & Rendah & 82 & Rendah & 0 \\
\hline 10 & FJ & 81 & Rendah & 79 & Rendah & 2 \\
\hline \multicolumn{2}{|r|}{ Jumlah } & \multicolumn{2}{|c|}{1180} & \multicolumn{2}{|c|}{1033} & 174 \\
\hline & Rata-rata & 188 & Sedang & 103,3 & Sedang & \\
\hline
\end{tabular}

Berdasarkan tabel 7, diketahui bahwa terdapat perubahan hasil pretest dan posttest kelompok kontrol. Sebelum diberikan layanan bimbingan kelompok perilaku bullying siswa berada pada kategori, tinggi 6 orang siswa, sedang 2 orang siswa, dan rendah 2 orang. Kemudian, perubahan terjadi ke arah yang lebih baik atau dengan kata lain kelompok kontrol mengalami penurunan skor stres akademik karena diberikan perlakuan layanan bimbingan kelompok tanpa menggunakan pendekatan REBT dari kategori sedang 7 orang siswa dan rendah 3 orang siswa.

\section{Rekapitulasi hasil pretest dan posttest kelompok eksperimen dan kontrol}

Berdasarkan data hasil pretest dan posttest kelompok eksperimen dan kelompok kontrol, dapat dilihat perbedaan skor stres akademik siswa pada tabel berikut:

Tabel 8. Rekapitulasi hasil pretest dan posttest kelompok eksperimen dan kontrol

\begin{tabular}{cccccccc}
\hline \multicolumn{7}{c}{ Kelompok Eksperimen } & \multicolumn{2}{c}{ Perilaku Bullying } \\
\hline Kode Siswa & Pretest & Postest & Selisih & Kode Siswa & Pretest & Postest & Selisih \\
\hline RFN & 146 & 98 & 48 & ZK & 142 & 120 & 22 \\
\hline IKM & 141 & 99 & 42 & TR & 140 & 114 & 26 \\
\hline MLK & 138 & 84 & 54 & FR & 138 & 112 & 26 \\
\hline NB & 137 & 81 & 56 & FS & 137 & 114 & 23 \\
\hline RR & 136 & 83 & 53 & FD & 135 & 110 & 25 \\
\hline GN & 135 & 76 & 59 & IBN & 132 & 115 & 17 \\
\hline RZ & 103 & 63 & 40 & KZ & 97 & 95 & 2 \\
\hline FR & 98 & 54 & 44 & RM & 96 & 92 & 4 \\
\hline ADL & 81 & 57 & 24 & EZ & 82 & 82 & 0 \\
\hline FD & 79 & 58 & 21 & FJ & 81 & 79 & 2 \\
\hline Jumlah & 1195 & 753 & 441 & Jumlah & 1180 & 1033 & 174 \\
\hline Rata-rata & 119,5 & 75,3 & 44,1 & Rata-rata & 118 & 103,3 & 17,4 \\
\hline
\end{tabular}

Berdasarkan tabel 8, diperoleh rata-rata pretest kelompok eksperimen sebesar 199.5 berada pada kategori sedang dan posttest sebesar 75,3 menurun menjadi rendah, sedangkan selisih skor pretest dan posttest adalah 441 dengan rata-rata selisih keseluruhan adalah 44,1. Pada pretest kelompok kontrol diperoleh rata-rata skor adalah 118 berada pada kategori sedang dan hasil posttest rata-rata skor sebesar 103,3 berada pada kategori sedang, sedangkan selisih skor pretest dan postest sebesar 174. Hal ini berarti kelompok eksperimen dan kelompok kontrol mengalami penurunan skor perilaku bullying setelah diberikan perlakuan, tetapi penurunan sikap siswa kelompok eksperimen dengan pendekatan rational emotive behavior therapy melalui format kelompok lebih besar dari kelompok kontrol dengan layanan bimbingan kelompok tanpa menggunakan pendekatan rational emotive behavior therapy. 


\section{Uji hipotesis}

Hipotesis penelitian ini tentang pendekatan rational emotive behavior therapy dalam mengatasi perilaku bullying peserta didik, adalah sebagai berikut:

H1: Terdapat perbedaan skor yang signifikan perilaku bullying siswa kelompok eksperimen sebelum dan sesudah diberikan perlakuan pendekatan rational emotive behavior therapy format kelompok; skor yang diperoleh kelompok eksperimen sesudah diberi perlakuan lebih rendah daripada skor yang diperoleh sebelum diberi perlakuan menggunakan pendekatan rational emotive behavior therapy format kelompok.

H0: Tidak terdapat perbedaan skor yang signifikan perilaku bullying siswa kelompok eksperimen sebelum dan sesudah diberikan perlakuan pendekatan rational emotive behavior therapy format kelompok.

H1: Terdapat perbedaan skor yang signifikan perilaku bullying siswa kelompok kontrol sebelum dan sesudah diberikan perlakuan tanpa mengunakan pendekatan rational emotive behavior therapy format kelompok; skor yang diperoleh kelompok kontrol tanpa diberi perlakuan lebih rendah daripada skor yang diperoleh sebelum diberi perlakuan tanpa menggunakan pendekatan rational emotive behavior therapy format kelompok.

H0: Tidak terdapat perbedaan skor yang signifikan perilaku bullying siswa kelompok kontrol sebelum dan sesudah diberikan perlakuan tanpa mengunakan pendekatan rational emotive behavior therapy format kelompok.

H1: Terdapat perbedaan yang signifikan perilaku bullying siswa antara kelompok eksperimen yang diberikan perlakuan menggunakan pendekatan rational emotive behavior therapy format kelompok, dengan kelompok kontrol yang diberikan perlakuan tanpa menggunakan pendekatan rational emotive behavior therapy format kelompok, skor kelompok eksperimen yang diberi perlakuan menggunakan pendekatan rational emotive behavior therapy format kelompok lebih rendah daripada skor kelompok kontrol yang diberi perlakuan tanpa menggunakan pendekatan rational emotive behavior therapy format kelompok.

H0: Tidak terdapat perbedaan yang signifikan perilaku bullying siswa antara kelompok eksperimen yang diberikan perlakuan menggunakan pendekatan rational emotive behavior therapy format kelompok, dengan kelompok kontrol yang diberikan perlakuan tanpa menggunakan pendekatan rational emotive behavior therapy format kelompok.

Adapun kriteria pengambilan keputusan pengujian hipotesis sebagai berikut (Siegel, 2011).

a. Terima H0 dan tolak H1 apabila probabilitas (sig 2-tailed) $>$ alpha $(\alpha=0,05)$.

b. Tolak H0 dan terima H1 apabila probabilitas (sig 2-tailed) $\leq$ alpha $(\alpha=0,05)$.

Berdasarkan hipotesis penelitian, maka untuk melakukan uji hipotesis akan dianalisis melalui statistik nonparametrik dengan uji Wilcoxon's dan Kolmogorov Smirnov 2 Independent, perhitungan dilakukan dengan menggunakan bantuan SPSS versi 20.00, sehingga data yang diperoleh lebih jelas. Penggunaaan uji Wilcoxon's adalah untuk menganalisis data sebelum dan setelah perlakuan dengan melihat perbedaan yang dialami baik kelompok eksperimen maupun kelompok kontrol.

Sebelum diberikan perlakuan, skor kelompok eksperimen dan kelompok kontrol harus setara. Oleh karena itu, hasil data pretest kelompok eksperimen dan kelompok kontrol dianalisis dengan menggunakan uji Kolmogorov Smirnov 2 Independent dengan bantuan SPSS versi 20.00, maka diperoleh hasil perhitungan seperti tabel berikut.

Tabe1 9. Hasil analisis kolmogorov smirnov 2 independent

\begin{tabular}{|c|c|c|}
\hline \multicolumn{3}{|c|}{ Test Statisticsa } \\
\hline & & Pretest \\
\hline \multirow[t]{3}{*}{ Most Extreme Differences } & Absolute & 200 \\
\hline & Positive &, 100 \\
\hline & Negative &,- 200 \\
\hline \multicolumn{2}{|c|}{ Kolmogorov-Smirnov Z } & ,447 \\
\hline \multicolumn{2}{|c|}{ Asymp. Sig. (2-tailed) } & ,988 \\
\hline
\end{tabular}

Berdasarkan data Tabel 9, dapat dilihat bahwa perilaku bullying peserta didik pada kolom Asymp. Sig. (2tailed)/significances untuk uji dua sisi adalah 0.988 yang dengan bentuk lain 0,988 $>0,05$. Maka tidak terdapat pebedaan yang signifikan perilaku bullying peserta didik kelompok eksperimen dan kontrol sebelum diberikan perlakuan. Hal ini dapat disimpulkan bahwa perilaku bullying siswa kelompok eksperimen dan kelompok kontrol setara. 


\section{Uji hasil pretes dan posttes kelompok ekperimen}

Hipotesis pertama yang diajukan dalam penelitian ini adalah terdapat perbedaan Perilaku bullying siswa kelompok eksperimen sebelum dan sesudah diberikan perlakuan pendekatan rational emotive behavior therapy. Pengujian hipotesis ini dilakukan dengan teknik analisis statistik Wilcoxon Signed Ranks Test melalui program SPSS versi 20.00. berdasarkan hal tersebut didapat hasil perhitungan seperti yang terangkum pada tabel berikut.

Tabel 10. Hasil analisis wilcoxon signed ranks test perilaku bullying siswa pada pretest dan posttest Kelompok Eksperimen

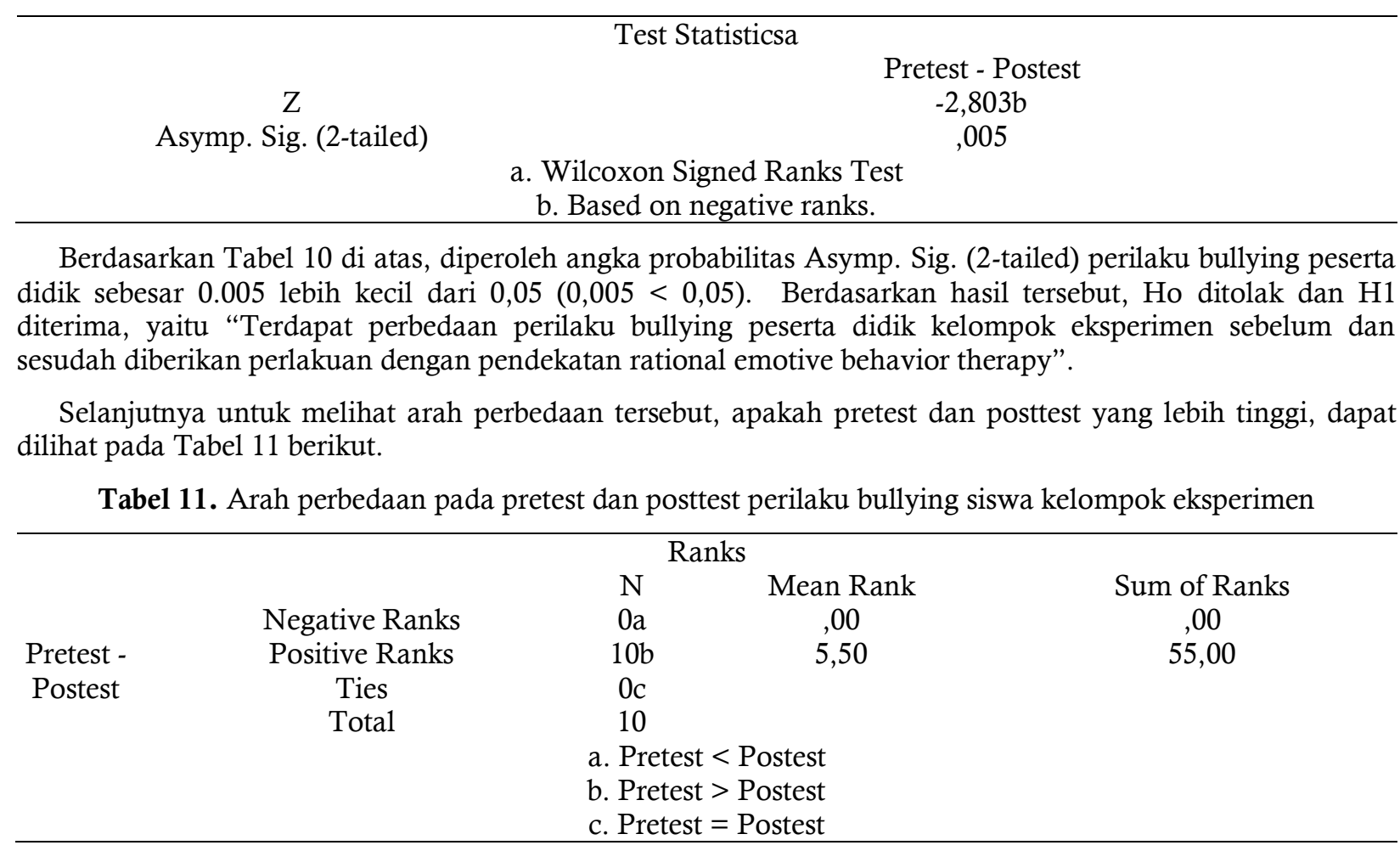

Berdasarkan Tabel 11nilai 10b berarti bahwa dari 10 responden kelompok eksperimen yang dilibatkan dalam perhitungan, seluruhnya mengalami penurunan skor secara signifikan dari pretest ke posttest dan tidak terdapat siswa yang mengalami peningkatan. Berdasarkan hasil di atas, dapat disimpulkan bahwa kelompok eksperimen mengalami penurunan perilaku bullying sesudah mendapatkan perlakuan pendekatan rational emotive behavior therapy format kelompok.

Sesuai dengan penjelasan di atas dapat dinyatakan bahwa peserta didik di dalam kelompok eksperimen secara keseluruhan berada pada Positive ranks, artinya perilaku bullying bullying siswa pada posttest lebih rendah dari nilai pretest dengan peringkat 5.50 dan jumlah dari peringkatnya adalah 55.00.

\section{Uji hasil pretes dan posttes kelompok kontrol}

Hipotesis kedua dalam penelitian ini adalah terdapat perbedaan perilaku bullying siswa kelompok kontrol sebelum dan sesudah diberikan perlakuan tanpa menggunakan pendekatan rational emotive behavior therapy. Pengujian hipotesis ini dilakukan dengan teknik analisis statistik Wilcoxon Signed Ranks Test melalui program komputer SPSS versi 20.00. berdasarkan hal tersebut didapat hasil perhitungan seperti terangkum pada tabel 28 berikut.

Tabel 12. Hasil analisis wilcoxon signed ranks test perbedaan perilaku bullying siswa pada posttest dan pretest kelompok kontrol

\begin{tabular}{ccc}
\hline & \multicolumn{1}{c}{ Test Statisticsa } & Pretest - Postest \\
$Z$ & $-2,670 \mathrm{~b}$ \\
Asymp. Sig. (2-tailed) & 008 \\
& a. Wilcoxon Signed Ranks Test \\
& b. Based on negative ranks. \\
\hline
\end{tabular}


Berdasarkan Tabel 12, diperoleh angka probabilitas Asymp. Sig. (2-tailed) perilaku bullying siswa sebesar 0,008 lebih kecil dari $0,05(0,008<0,05)$. Berdasarkan hasil tersebut, Ho ditolak dan H1 diterima, yaitu "Terdapat perbedaan perilaku bullying siswa kelompok kontrol sebelum dan sesudah diberikan perlakuan tanpa menggunakan pendekatan rational emotive behavior therapy".

Untuk melihat arah perbedaan tersebut, apakah pretest dan posttest yang lebih tinggi, dapat dilihat pada Tabel 13 di bawah ini.

Tabel 13. Perbedaan pada pretest dan posttest perilaku bullying siswa kelompok kontrol

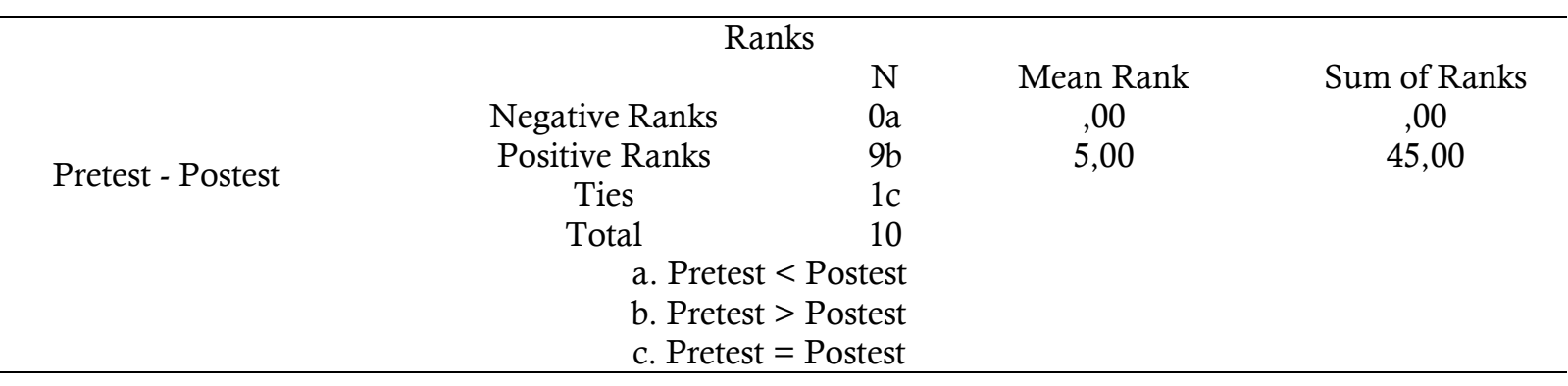

Berdasarkan Tabel 13, diketahui nilai $9 \mathrm{~b}$ pada positive ranks berarti bahwa 9 orang siswa mengalami penurunan sesudah diberi perlakuan, kemudian nilai 1c pada ties berarti bahwa 1 orang siswa memiliki skor pretest $=$ posttest, artinya tidak ada peningkatan dan penurunan

Sesuai dengan penjelasan di atas dapat dinyatakan bahwa siswa di dalam kelompok kontrol 9 orang berada pada Positive ranks, dan 1 orang berada pada ties artinya perilaku bullying peserta didik pada posttest lebih rendah dari nilai pretest dengan peringkat 5.00 dan jumlah dari peringkatnya adalah 45.00 .

\section{Uji hasil posttes kelompok ekperimen dengan kontrol}

Pengujian hipotesis ketiga yang diuji adalah "Terdapat perbedaan perilaku bullying siswa kelompok eksperimen yang diberikan perlakuan pendekatan rational emotive behavior therapy dan kelompok kontrol yang tidak diberikan perlakuan pendekatan rational emotive behavior therapy. Berdasarkan teknik tersebut, hasil pengujian analisis tes Kolmogorov Smirnov 2 Independent pada posttest terangkum pada tabel berikut.

Tabel 14. Hasil analisis kolmogorov smirnov 2 independent pada posttest perilaku bullying siswa kelompok eksperimen dan kelompok kontrol

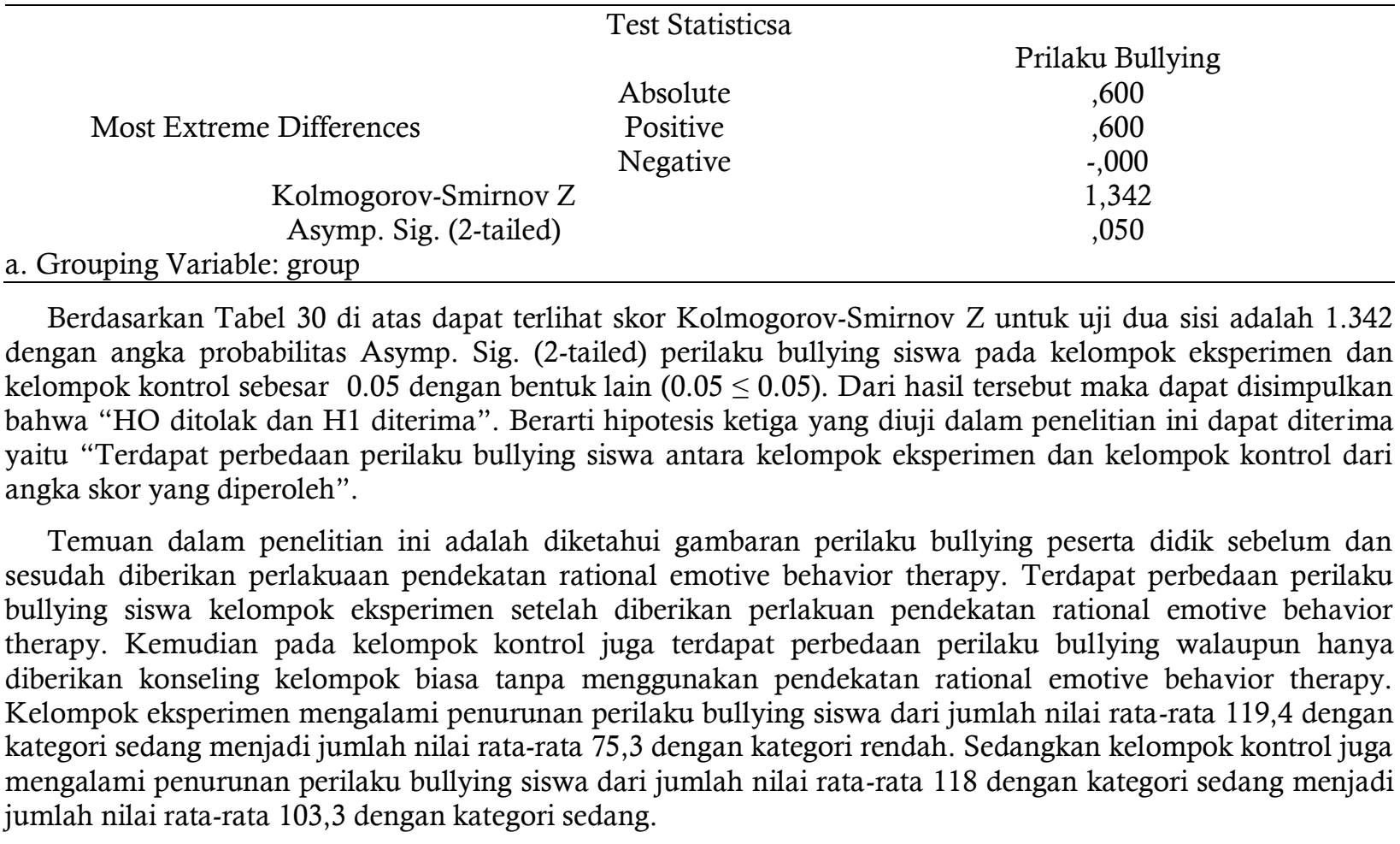




\section{Perbedaan perilaku bullying kelompok eksperimen sebelum dan sesudah diberikan pendekatan Rational} Emotive Behavior Therapy

Hasil penelitian menunjukkan bahwa pendekatan rational emotive behavior therapy dalam format kelompok efektif dalam mengatasi perilaku bullying peserta didik. Hal ini dapat dilihat dari hasil perbandingan pretest dengan postest yang menunjukkan hasil pretest bahwa 6 orang siswa yang memiliki perilaku bullying tinggi, 2 orang kategori sedang, dan 2 orang kategori rendah. Semua anggota kelompok mengalami penurunan perilaku bullying ke tingkatan yang rendah dari sebelumnya setelah diberikan pendekatan rational emotive behavior therapy dalam format kelompok. Hal ini terlihat dari hasil postest yang menunjukkan bahwa 6 orang peserta didik dengan kategori tinggi, 2 orang kategori sedang dan 2 orang katagori rendah dan tidak ada anggota kelompok yang memiliki perilaku bullying tinggi dan sangat tinggi. Winkel, menjelaskan konseling rational emotive behaviorterapi merupakan corak konseling yang menekankan kebersamaan dan reaksi antara berpikir dan akal sehat (rational emotive), berperasaan (emoting), dan berprilaku (acting) (Dryden, 2006)

Tujuan rational emotive behavior therapy adalah untuk memperbaiki dan merubah sikap, persepsi, cara berpikir, keyakinan serta pandangan-pandangan konseli yang irasional dan tidak logis menjadi pandangan yang rasional dan logis agar peserta didik dapat mengembangkan diri, meningkatkan aktualisasi dirinya seoptimal mungkin melalui tingkah laku kognitif dan afektif yang positif (Bernard \& Dryden, 2019)

Sesudah siswa diberikan pelakuan pendekatan rational emotive behavior therapy dalam kelompok, skor posttest mengalami penurunan skor. Perolehan skor posttest kelompok eksperimen sebesar 753, dengan nilai mean sebesar 75,3 dan skor perilaku bullying siswa berada pada kategori rendah. Selisih skor nilai mean perilaku bullying siswa sebelum dan sesudah diberikan perlakuan sebesar 44,1. Jadi, penurunan skor yang terjadi adalah sebesar 441. Perbedaan perolehan skor perilaku bullying tersebut adalah akibat diberikan pendekatan rational emotive behavior therapy dalam format kelompok.

Selain itu perbedaan perilaku bullying sebelum dan sesudah perlakuan berupa pendekatan REBT dalam format kelompok dibuktikan dengan uji hipotesis angka probabilitas sig Asymp. Sig. (2-tailed) perilaku bullying sebesar 0,005 atau probabilitas di bawah alpha $(0,005<0,05)$. Berdasarkan hasil tersebut, Ho ditolak dan Ha diterima. Dengan demikian, terdapat perbedaan perilaku bullying kelompok eksperimen sebelum dan sesudah diberikan perlakuan pendekatan rational emotive behavior therapy dalam format kelompok

Pendekatan rational emotive behaviour therapy merupakan salah satu terapi kognitif perilaku yang memfokuskan pada membantu individu bukan hanya untuk merasa lebih baik, tetapi dengan mengubah pemikiran dan perilakunya, menjadi lebih baik (rasional) (Hermawan, 2014).

Pendekatan rational emotive behavior therapy memandang bahwa perilaku manusia adalah hasil dari proses berfikir atas suatu keadaan, dan reaksi emosi sehat dan tidak sehat tergantung pada bagaimana individu menginterpretasikan suatu keadaan tersebut (Konadi, 2019).

Permasalahan yang timbul dan dialami oleh individu dalam pandangan rational emotive behaviour therapy diakibatkan karena sistem keyakinan yang tidak rasional. Sehingga diperlukan usaha yang mampu mengubah keyakinan tersebut menjadi lebih rasional. Menurut Ellis dalam Richard Nelson Jones, formula yang ditawarkan untuk mengubah keyakinan yang tidak rasional adalah dengan cara melawannya (disputing), yang dalam teori ini digambarkan dengan urutan A (activating event), B (believe), C (consequences), D (disputing), E (effective) (Johnsen, 2013)

\section{Perbedaan perilaku bullying kelompok kontrol sebelum dan sesudah diberikan pendekatan Rational} Emotive Behavior Therapy

Berdasarkan analisis data diketahui bahwa pada kelompok kontrol terdapat perbedaan perilaku bullying siswa sebelum diberikan layanan konseling kelompok (tanpa pendekatan REBT) dengan perilaku bullying setelah diberikan layanan konseling kelompok (tanpa pendekatan REBT). Sebelum diberikan perlakukan, skor total perilaku bullying kelompok kontrol adalah sebesar 1180 dengan skor rata-rata 180. Berdasarkan perolehan skor sebelum perlakukan, perilaku bullying kelompok kontrol berada pada kategori tinggi.

Setelah diberikan perlakukan yaitu dengan konseling kelompok (tanpa pendekatan REBT) terjadi penurunan perilaku bullying kelompok kontrol. Skor total perilaku bullying kelompok kontrol setelah diberikan perlakukan adalah 1033 dengan skor rata-rata 103,3 mengalami penurunan jika dibandingkan dengan skor perilaku bullying sebelum diberikan perlakukan. Selisih skor nilai mean perilaku bullying sebelum dan sesudah diberikan perlakuan sebesar 17,4. Jadi penurunan skor yang terjadi adalah sebesar 174. Meskipun secara statistik terdapat perbedaan dan penurunan skor perilaku bullying pada kelompok kontrol, terdapat 7 orang siswa yang berada kategori sedang dan 3 orang kategori rendah. 
Natawidjaya mengemukakan bahwa konseling kelompok merupakan upaya bantuan kepada individu dalam suasana kelompok yang bersifat pencegahan dan penyembuhan, dan diarahkan kepada pemberian kemudahan dalam rangka perkembangan dan pertumbuhannya (Fratiwi, 2018).

Layanan konseling kelompok yaitu "layanan bimbingan dan konseling yang memungkinkan siswa memperoleh kesempatan untuk pembahasan dan pengentasan permasalahan yang dialaminya melalui dinamika kelompok. Dinamika kelompok adalah suasana yang hidup, yang berdenyut, yang bergerak, yang berkembang, yang ditandai dengan adanya interaksi antara sesama anggota kelompok. Layanan konseling kelompok merupakan layanan konseling yang diselenggarakan dalam suasana kelompok (Prayitno, 2016).

Gadza menjelaskan menjelaskan bahwa "konseling kelompok merupakan suatu proses interpersonal yang dinamis yang memusatkan pada usaha dalam berfikir dan tingkah laku-tingkah laku, serta melibatkan pada fungsi-fungsi dari terapi yang dimungkinkan, serta berorientasi pada kenyataan-kenyatan, membersihkan jiwa, saling percaya mempercayai, pemeliharaan, pengertian, penerimaan dan bantuan. Fungsi-fungsi dari terapi itu diciptakan dari dipelihara dalam wadah kelompok kecil melalui sumbangan perorangan dalam anggota kelompok serta sebaya dan konselor". Konseling kelompok bersifat memberikan kemudahan dalam pertumbuhan dan perkembangan individu, dalam arti bahwa konseling kelompok memberikan dorongan dan motivasi kepada individu untuk membuat perubahan-perubahan dengan memanfaatkan potensi secara maksimal sehingga dapat mewujudkan diri" (Kurnanto, 2013).

Kemudian Tohirin menjelaskan konseling kelompok adalah suatu upaya pemberian bantuan kepada individu (siswa) yang mengalami masalah-masalah pribadi melalui kegiatan kelompok agar tercapai perkembangan yang optimal.Konseling kelompok mengikutkan sejumlah peserta dalam bentuk kelompok dengan konselor sebagai pemimpin kegiatan kelompok. Layanan konseling kelompok mengaktifkan dinamika kelompok untuk membahas berbagai hal yang berguna bagi pengembangan pribadi dan pemecahan masalah individu (siswa) yang menjadi peserta layanan (Tohirin, 2017).

Prayitno menjelaskan tujuan konseling kelompok yang intensif dalam upaya pemecahan masalah tersebut, para peserta memperoleh dua tujuan sekaligus yaitu: 1)Terkembangnya perasaan, pikiran, persepsi, wawasan dan sikap terarah kepada tingkah laku khususnya dan bersosialisasi dan berkomunikasi, 2)Terpecahnya masalah individu yang bersangkutan dan diperolehnya imbasan pemecahan masalah tersebut bagi individuindividu lain yang menjadi peserta layanan (Prayitno, 2004).

\section{Perbedaan perilaku bullying siswa kelompok eksperimen dan kontrol}

Pelaksanaan penelitian bertujuan untuk mengetahui efektifitas pendekatan rational emotive behavior therapy untuk mengatasi perilaku bullying siswa SMP Hamka II Padang. Hasil penelitian menunjukkan bahwa terdapat perbedaan perilaku bullying siswa pada kelompok eksperimen yang diberikan pendekatan rational emotive behavior therapy dalam format kelompok dengan kelompok kontrol yang di berikan layanan konseling kelompok tanpa menggunakan pendekatan rational emotive behavior therapy.

Uji hipotesis dengan two-sample kolmogorov-smirnov test membuktikan bahwa nilai asymp. Sig. (2-tailed) 0.05 dengan bentuk lain $(0.05 \leq 0.05)$. Dengan demikian disimpulkan bahwa terdapat perbedaan perilaku bullying kelompok eksperimen dan kelompok kontrol. Kedua kelompok penelitian diberikan layanan yang sama yaitu layanan konseling kelompok, namun pada kelompok eksperimen diberikan layanan konseling kelompok dengan menggunakan pendekatan rational emotive behavior therapy.

Penedekatan rational emotive behavior terapi dalam format kelompok merupakan tempat bersosialisasi dengan anggota kelompok dan masing-masing anggota kelompok akan memahami dirinya dengan baik (Komalasari, 2011). Berdasarkan pemahaman diri itu dia lebih rela menerima sendiri dan lebih terhadap aspek-aspek positif dalam kepribadiannya, selain itu dinamika kelompok sudah dapat tercipta dengan baik ikatan batin yang terjalin antar anggota kelompok akan lebih mempererat hubungan dintara mereka sehingga masing-masing individu akan merasa diterima dan dimengerti oleh orang lain serta timbul penerimaan dirinya.

Pendekatan rational emotive behavior therapy memandang bahwa prilaku manusia adalah hasil dari proses berfikir atas suatu keadaaan, dan reaksi emosi sehat dan tidak sehat tergantung pada bagaimana individu menginterpretasikan suatu keadaan tersebut. Sementara prosedur tercapainya proses kedisiplinan ialah bagaimana individu mengendalikan dan mengontrol mobilitas pikiran, emosi, dan perilaku dari hasrat atas kondisi eksternal dan internal yang dapat menggagalkan tujuan (Denise T.D. de Ridder, 2006).

Pelaksanaan proses bimbingan dan konseling akan dapat membuahkan hasil yang optimal, apabila di dalam pelaksanaannya menggunakan tehnik-tehnik bimbingan dan konseling secara tepat, sehingga kemampuan kreatifitas siswa berkembang secara optimal. 
Setelah diadakan posttest dan setelah dilakukan pengujian hipotesis diperoleh kesimpulan bahwa pendekatan rational emotive behavior therapy efektif untuk mengatasi perilaku bullying siswa SMP Hamka II Padang.

\section{Simpulan}

Berdasarkan hasil penelitian yang diperoleh, secara umum dapat disimpulkan bahwa pendekatan rational emotive behavior therapy dalam format kelompok efektif untuk mengatasi perilaku bullying siswa. Secara khusus temuan penelitian ini sebagai berikut. 1) Terdapat perbedaan yang signifikan perilaku bullying siswa kelompok eksperimen sebelum dan sesudah mengikuti pendekatan rational emotive behavior therapy format kelompok. 2) Terdapat perbedaan yang signifikan perilaku bullying siswa kelompok kontrol sebelum dan sesudah mengikuti layanan bimbingan kelompok tanpa menggunakan pendekatan rational emotive behavior therapy. 3) Terdapat perbedaan yang signifikan perilaku bullying siswa kelompok eksperimen yang diberikan pendekatan rational emotive behavior therapy format kelompok dengan peserta didik kelompok kontrol yang diberikan layanan konseling kelompok tanpa pendekatan rational emotive behavior therapy. kelompok eksperimen dan kontrol sama-sama mengalami penurunan, akan tetapi rata-rata penurunan kelompok eksperimen lebih besar pada kelompok kontrol. Dari tiga poit tersebut dapat disimpulkan bahwa penggunaan pendekatan rational emotive behavior therapy format kelompok dan layanan konseling kelompok tanpa pendekatan rational emotive behavior therapy dapat menurunkan perilaku bullying siswa, akan tetapi menurunkan perilaku bullying siswa lebih efektif apabila menggunakan pendekatan rational emotive behavior therapy format kelompok.

\section{Referensi}

Ani Wardah, Dan F. (2019). Pelatihan Asertivitas Untuk Meningkatkan Perilaku Asertif Peserta Didik SMP Korban Bullying. Ejournal Psikologi, 1-5.

Bernard, M. E., \& Dryden, W. (2019). Advances In Rebt Theory, Practice, Research, Promotion. (Michael E. Bernard - Windy Dryden, Ed.), Advances In Rebt (Advances I). Australia. Https://Doi.Org/10.1007/9783-319-93118-0

Denise T.D. De Ridder, J. B. (2006). Self-Regulation In Health Behavior. England. Indonesian Journal Of Educational Counseling, 1(1), 53-78. Https://Doi.Org/10.30653/001.201711.6

Dryden, W. (2006). First Steps In Rebt : A Guide To Practicing Rebt In Peer Counseling (First Edit). New York: New York, Ny Albert Ellis Institute Windy.

Fratiwi, M. E. (2018). Efektivitas Konseling Kelompok Rational Emotive Behaviour Therapyuntuk Meminimalisir Tingkat Pergaulan Bebas Siswa Kelas XI Akutansi SMK 17 Agustus 1945 Muncar. Jurnal Keperawatan Jiwa, 7, 159-164.

Hermawan, A. (2014). Konseling Rational Emotive Behaviour Therapy Berbasis Islam untuk Meningkatkan Self Efficacy Peserta Didik MTS Nurul Huda Demak. Jurnal Bimbingan Konseling, 85.

Johnsen. (2013). Springer Briefs In Psychology The Abcs Of Rebt Revisited. Leadership \& Organization Development Journal (Vol. 28). London. Retrieved From Http://Link.Springer.Com/10.1007/978-94-007-5222

Komalasari. (2011). Teori Dan Teknik Konseling. Jurnal Bimbingan Dan Konseling, $12-35$. Http://Dx.Doi.Org/10.1016/J.Saa.2017.10.076\%0ahttps://Doi.Org/10.1016

Konadi, H. (2019). Efektivitas Pendekatan Rational Emotive Behavior Therapy Melalui Bimbingan Kelompok Untuk Mengatasi Stres Akademik Siswa. Ejournal Psikologi, 2019. Jurnal Psikologi, 5(2), 94101.

Kurnanto. (2013). Konseling Kelompok. Bandung. Jbki (Jurnal Bimbingan Konseling Indonesia). Http://Ec.Europa.Eu/Energy/Res/Legislation/Doc/Biofuels/2006_05_05_Consultation_En.Pdf\%0ah

Nurhadiyanto, L., \& Luhur, U. B. (2020). Analisis Cyber Bullying Dalam Perspektif Teori. Jurnal Ikra-Ith Humaniora, 4(2), 113-124.

Prayitno. (2004). Layanan Bimbingan Kelompok Konseling Kelompok. Padang. Bandung: Abkin, 1(1), 1-14. Retrieved From Www.Unissula.Ac.Id

Prayitno. (2016). Layanan Bimbingan Kelompok Dan Konseling Kelompok (Seri Layanan Pendukung Konseling L.1L.9) (Vol. 645). Padang: Unp Press.

Putra, S. E. (2020). Pengaruh Videotherapyterhadap Pengetahuan Dan Kesadaran Anti-Bullyingdi Sekolah Pada Anak Usia Sekolah Di Sd Negeri 02 Lubuk Buaya Kota Padang. Ejournal Psikologi, 66, 37-39.

Sri Rahma Yanti. (2020). Analisis Kejadian Bullyingdan Hubungannya Dengan Resiliensi Pada Anak Difablefisik Di Sekolah Luar Biasa Kota Padang. International Journal Of Machine Tools And Manufacture, 5(1), 86-96. Https://Doi.Org/10.1016/J.Ijmachtools.2009.09.004

Tohirin. (2017). Bimbingan Konseling Di Sekolah Dan Madrasah. Jakarta. Jki (Jurnal Konseling Indonesia), 
192(4), 121-130. Retrieved From Http://Jurnal.Fkip.Unila.Ac.Id/Index.Php/Alib/Article/View/20415 Yanti, S. R. I. R. (2020). Analisis Kejadian Bullying Dan Hubungannya Di Sekolah Luar Biasa Kota Padang Program Studi Ilmu Keperawatan. Ejournal Psikologi. 